\title{
IDO-14582 MASTER
}

SODIUM FLUOZIRCONATE PRECIPITATION PROCESS

FOR ZIRCONIUM FUELS

PART I. LABORATORY DEVELOPMENT

\section{B. J. Newby}

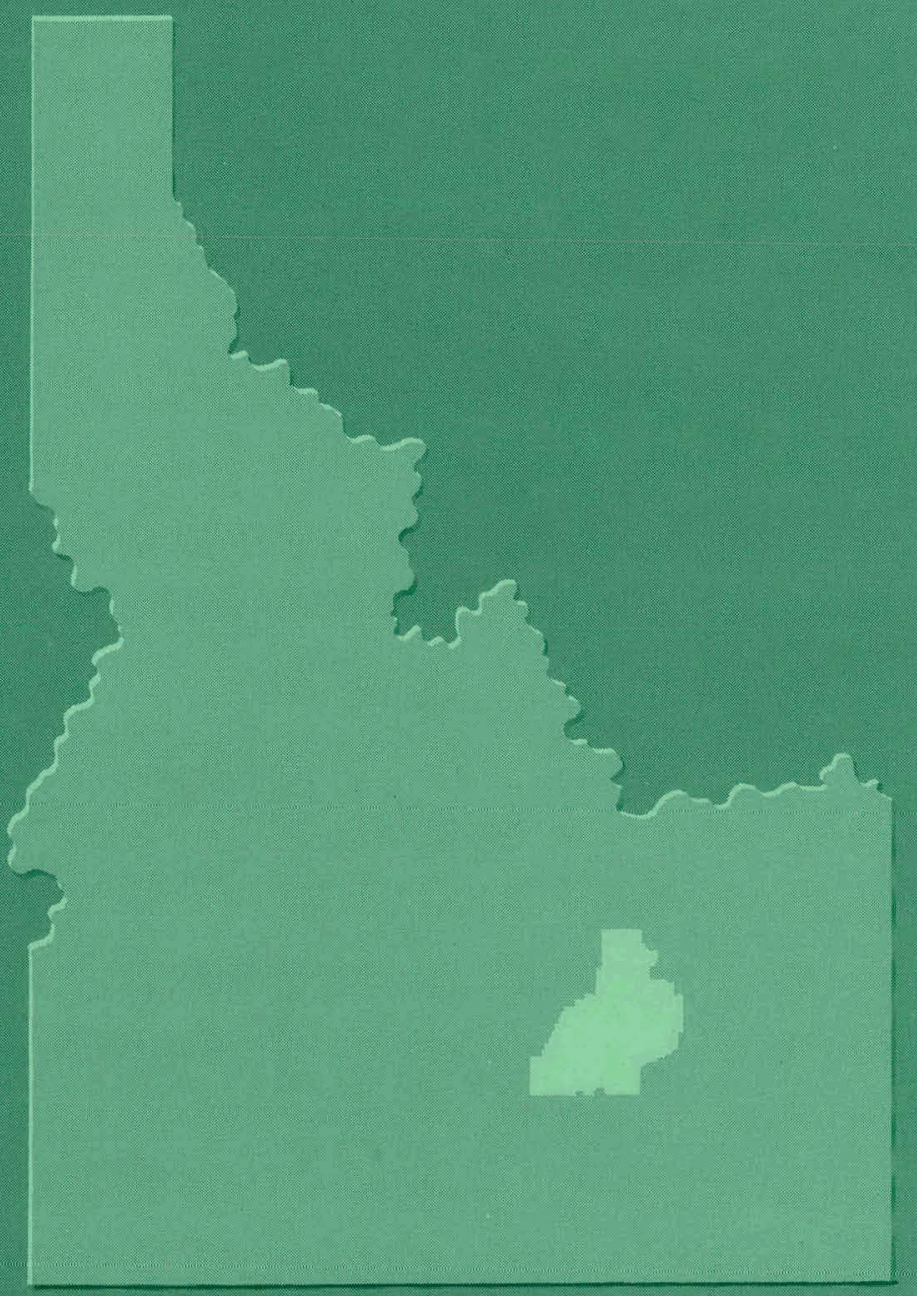

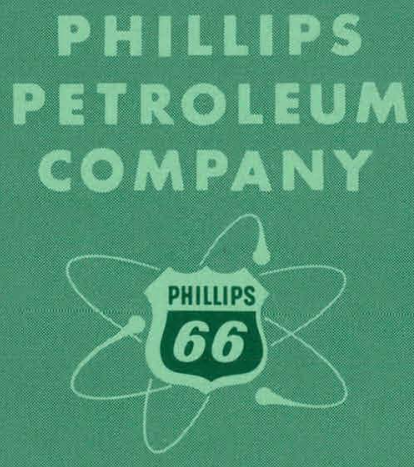

ATOMIC ENERGY DIVISION

NATIONAL REACTOR TESTING STATION 


\section{DISCLAIMER}

This report was prepared as an account of work sponsored by an agency of the United States Government. Neither the United States Government nor any agency Thereof, nor any of their employees, makes any warranty, express or implied, or assumes any legal liability or responsibility for the accuracy, completeness, or usefulness of any information, apparatus, product, or process disclosed, or represents that its use would not infringe privately owned rights. Reference herein to any specific commercial product, process, or service by trade name, trademark, manufacturer, or otherwise does not necessarily constitute or imply its endorsement, recommendation, or favoring by the United States Government or any agency thereof. The views and opinions of authors expressed herein do not necessarily state or reflect those of the United States Government or any agency thereof. 


\section{DISCLAIMER}

Portions of this document may be illegible in electronic image products. Images are produced from the best available original document. 


\section{PRICE \$.75}

\section{Available from the Office of Technical Services \\ U. S. Department of Commerce \\ Washington 25, D. C.}

\section{LEGAL NOTICE}

This report was prepared as an account of Government sponsored work. Neither the United States, nor the Commission, nor any person acting on behalf of the Commission:

A. Makes any warranty or representation, express or implied, with respect to the accuracy, completeness, or usefulness of the information contained in this report, or that the use of any information, apparatus, method, or process disclosed in this report may not infringe privately owned rights; or

B. Assumes any habilities with respect to the use of, or for damages resulting from the use of any information, apparatus, method, or process disclosed in this report.

As used in the above, "person acting on behalf of the Commission" includes any employee or contractor of the Commission, or employee of such contractor, to the extent that such employee or contractor of the Commission, or employee of such contractor prepares, disseminates, or provides access to, any information pursuant to his employment or contract with the Commission, or his employment with such contractor. 


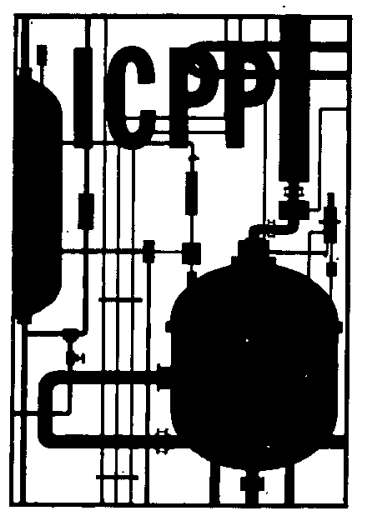

IDO -14582 AEC Research and Development Report Chemical Separations Processes for Plutonium and Uranium TID-4500, Ed. 17 Issued: May 15, 1962

\section{SODIUM FLUOZIRCONATE PRECIPITATION PROCESS}

FOR ZIRCONIUM FUELS

\section{PART 1. LABORATORY DEVELOPMENTT}

B. J. Newby

\section{PHILLIPS}

\section{PETROLEUM}

COMPANY

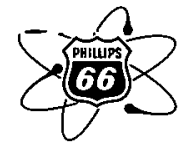

Atomic Energy Division

Contrnct AT(10.1)-205 Idaho Operations Office 
THIS PAGE

\section{WAS INTENTIONALLY \\ LEFT BLANK}


SODIUM FLUOZIRCONATE PRECIPITATION PROCESS

FOR ZIRCONIUM FUELS

PART 1. LABORATORY DEVELOPMENT

B. J. Newby

TABLE OF CONTENTS

Page

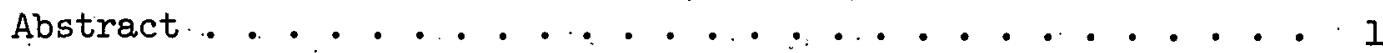

I. Summary ... . . . . . . . . . . . . . . . . 2

II. Introduction . . . . . . . . . . . . . . . 4

III. Sodium Formate Flowsheets . . . . . . . . . . . 6

A. Flowsheet Utilizing. Two Solid-Liquid Separations . . . . 7

B. Flowsheet Utilizing One Solid-Liquid Separation . . . . 7

IV. Conclusions . . . . . . . . . . . . . . . 10

V. Literature Clted . . . . . . . . . . . . . 15

VI. Appendix . . . . . . . . . .......... 16

A. Experimental Methods and Materials . . . . . . . 16

1. Zirconium Alloy Fuel Solutions . . . . . . . 16

2. Equipment and Procedure .......... 16

3. Analytical Methods . . . . . . . . . . . 16

B. Precipitation of Zirconium and Fluoride with Sodium Formate $] 7$.

1. Effect of Sodium Formate Concentration . . . . . . 17

2. Effect of Reaction Time . . . . . . . . . . . . 18

3. Wash Solution Studies . . . . . . . . . . . . 18

4. Effect of Temperature and Flocculating Agents . . . . 21

5. Fluoride and Zirconium Concentrations in Dissolver

Solution . . . . . . . . . . . . . . . 22

6. Corrosion . . . . . . . . . . . . . . . 22

C. Boildown and Extraction Studies . . . . . . . . 22

1. Boildown with Solid Formation, Followed by Extraction 22

a. Boildown Studies . . . . . . . . . . 25

b. Wash Solution Studies . . . . . . . . . 25

c. Solution Adjustment Prior to Extraction . . . 27

2. Boildown Without Solid Formation, Followed by

3. Corrosion ................. 30 


\section{LIST OF TABLES}

Table 1 Material Balance for Sodium Formate Headend

Page

Precipitation Using Two Solid-Liquid Separations . . . 9

Table 2 Material Balance for Sodium Formate Headend

Precipitation Using One Solid-Liquid Separation . . . 12

Table 3 Effect of Various Wash Solutions on Uranium Removal and Precipitate Solubility . . . . . . . . . . 19

Table 4 Effect of Fluoride-to-Zirconium Mole Ratio on Sodium Formate Precipitation ... . . . . . . . 23

Table 5 Corrosion During the Precipitation 'of' Zirconium and Fluoride with Sodium Formate .......... 24

Table 6 Boildown Characteristics of Filtrates and $0.1 \mathrm{M}$ Sodium Nitrate Wash Solutions Produced During Sodium Formate Precipitation . . . . . . . . 26

Table 7 Boildown and Extraction Characteristics of Filtrates Produced During Sodium Formate Precipitation Followed by a 0.1M Nitric Acid or Sodium Nitrate Wash . . . . 29

Table 8 Corrosion During the Boildown of Filtrates and Wash Solutions Formed from the Precipitation of Zirconium and Fluoride with Sodium Formate . . . . . . . 31

\section{LIST OF FIGURES}

Figure 1 Flowsheet for Sodium Formate Headend Precipitation Using Two Solid-Liquid Separations . . . . . . 8

Figure 2 Flowsheet for Sodium Formate Headend Precipitation Using One Solid-Liquid Separation . . . . . . . II

Figure 3 Effect of Sodium Formate Concentration on Zirconium Recovery..................... 17

Figure 4 Effect of Reaction T'ime on Zirconium Recovery . . . 18

Figure 5. Uranium Equilibrium Curve for Precipitate Washing . • 21 
SODIUM FLUOZIRCONATE PRECIPITATION PROCESS

FOR ZIRCONIUM FUELS

PART 1. LABORATORY DEVELOPMENT

B. J. Newby

$\underline{A} \underline{B} \underline{\mathrm{S}} \underline{\mathrm{T}} \underline{\mathrm{R}} \underline{\mathrm{A}} \underline{\mathrm{C}} \underline{\mathrm{T}}$

In the reprocessing of zirconium-containing reactor fuels by hydrofluoric acid dissolution, significantly decreased waste volumes and increased column capacities can be,obtained by the headend precipitation of the bulk of the fluoride and zirconium. A sparingly soluble complex fluozirconate is formed when the dissolver solution is treated with sodium formate. Precipitation, evaporation, and extraction feed preparation conditions are established for this process. Ninety-five to 99 per cent of the zirconium and fluoride is. separated from the uranium with uranium losses of 0.1 per cent or less. Chemical material balances, based on experimental data, have been developed for two flowsheets. In one flowsheet, sufficient nitric acid is added to the combined wash solution and filtrate produced during the precipitation step to destroy the formate ion (which inhibits uranium extraction) and to prevent post-precipitation during the evaporation of these solutions. The other flowsheet calls for addition of sufficient nitric acid to destroy the formate ion, but not enough to prevent post-precipitation during the concentration step. Post-precipitation removes additional.zirconium and fluoride, but necessitates an additional solids-separation step. 


\section{SODIUM FLUOZIRCONATE PRECIPITATION PROCESS}

FOR ZIRCONIUM FUELS

\section{PART 1. LABORATORY DEVELOPMENT}

\section{B. J. Newby \\ I. SUMMARY}

Current Idaho Chemical Processing Plant (ICPP) zirconium fuel processing methods, and several new methods under development, produce large waste volumes. Removing both zirconium and fluoride as a solid from dissolver product solutions results in smaller waste -volumes; higher uranium throughputs" through extraction equipment, and-conversion of a portion of the waste to a solid. Each of these factors is of significanse in the diesign nf imprnver flowshert.s for pronessing fuels at the ICPP. The addition of sodium formate to hydrofluoric acid-zirconium fuel dissolver product solutions removes the zirconium and fluoride almost quantitatively from solutions as a precipitate.

The effective removal of zirconium and fluoride from solution requires two moles of sodium formate per mole of zirconium present. It is rapid at temperatures between 23 and $95^{\circ} \mathrm{C}$, and under controlled conditions is independent of the concentration of fluoride in the dissolver solution. Aqueous streams involved in the precipitation are only slightly corrosive to materials of construction comonly used for the chemical processing of uranium. Uranium loss to the precipitate is about 0.1 per cent for a zirconium-uranium fuel containing 2.5 per cent uranium when the uranium is in its highest state of oxidation and the precipitate is washed adequately.

Concentration of the supernatant solution and washes can be accomplished with or without the formation of solids, and the resultant concentrate can be adjusted to give good uranium extraction results when contacted with $10 \%$ tributyl phosphate in Amsco. A boildown performed on combined filtrates and wash solutions made $0.4 \mathrm{M}$ in nitric acid produces a post-precipitate which removes fluoride from solution. During such an evaporation, corrosion rates of $<0.04$ mil per month were found for Carpenter-20 in both the liquid and 
vapor phases. Evaporation of combined filtrates and wash solutions made 1.OM in nitric acid to prevent post-precipitation gives corrosion rates of about 3 mils per month. Uranium losses to boildown solids are about 0.03 per cent when the uranium is all oxidized and the solid washed 3 times with $0.1 \mathrm{M}$ nitric acid.

Two flowsheets are presented, differing in the type of boildown used. The flowsheet using a boildown resulting in formation of solids removes over 99 per cent of the zirconium, loses approximately 0.1 per cent of the uranium, and produces extraction column feeds equal to 20 per cent of the dissolver solution volume. The flowsheet utilizing solid-free boildown removes about 95 per cent of the zirconium, loses about 0.1 per cent of the uranium, and produces extraction column feed equal to 36 per cent of the dissolver solution volume. 


\section{INTRODUCTION}

Currently, the most successful methods for processing zirconiumuranium alloy reactor fuels involve dissolution with hydrofluoric acid containing an oxidant. The resulting solution is adjusted with aluminum nitrate to permit uranium extraction in stainless steel columns, and the raffinate stored without further treatment. The hydrofluoric acid process or the similar ammonium fluoride process produces large volumes of waste requiring long-term storage. The removal of zirconium and fluoride as a solid from the process solutions would convert the alloy constituents of the waste to a noncorrosive solid, thus allowing concentration of the liquid waste to $a$, small volume for storage or calcination. By removing most of the zirconium and fluoride prior to extraction, the amount of total waste solids can be reduced, because the need for large concentrations of aluminum nitrate to complex the fluoride ion is eliminated.

Extraction column feed can also be concentrated to smaller volumes, thereby increasing the uranium throughput of the extraction columns.

The addition of sodium formate to zirconium-hydrofluoric acid process solutions removes greater than 97 per cent of the zirconium and fluoride as a precipitate. Uranium loss is of the order of 0.1 per cent provided uranium is in the hexavalent state. Furthermore, the volume of filtrate and wash solutions can be reduced by evaporation to as little as 20 per cent of the volume of the original dissolver solution. After removal of solids, uranium can be extracted from the resulting filtrate with 10 per cent TBP in Amsco.

This report is intended to provide sufficient information for the selection of favorable conditions for removing zirconium and fluoride from dissolver solutions by precipitation with sodium formate. In addition, favorable conditions for boiling down the resulting filtrates and wash solutions with or without solids formation, and for extracting uranium from the resulting media with 10 per cent TBP in Amsco, are included. Hydrofluoric acid dissolver. solutions corresponding to the ICPP STR process were used because considerable information pertaining to the dissolution of zirconium- 
uranium alloy fuel in hydrofluoric acid is available. However, much of the data presented in this report can be applied to any hydrofluoric acid-zirconium fluoride process. Two different flowsheets together with a brief supporting description are given in the main body of the report. The information used to prepare these flowsheets was obtained from experiments described in the Appendix of this report. These experiments involved a study of the precipitation of zirconium and fluoride using sodium formate concentration, reaction time, temperature, flocculating agents, and dissolver solution composition as variables. The Appendix also contains a description of boildown and extraction studies, wash solution studies, and corrosion. studies under precipitation and boildown conditions. 


\section{SODTUM FORMATE FLOWSHEETS}

From the information obtained in the studies described in the Appendix, two tentative flowsheets were prepared. One flowsheet uses conditions which result in the elimination of solids during boildown; the other flowsheet requires two filtrations, the second being necessary to remove solids formed during boildown.

The washed precipitates obtained from the reaction of sodium formate. with solutions of zirconium and fluoride contained about 1.5 moles of sodium and 5 moles of fluoride for each mole of zirconium present. It was concluded that the precipitates contained no organic radical since carbon could not be detected. It was not possible to analyze for oxygen in the presence of the fluoride; therefore, there is no direct measure of the degree of hydrolysis. The X-ray pattern for the major crystalline species present was similar to the pattern given by $\beta \mathrm{Na}_{2} \mathrm{ZrF}_{6}$; however, there are many possible sodium fluozirconates, and patterns were available for only $\mathrm{Na}_{2} \mathrm{ZrF}_{6}$ and $\mathrm{NaZrF}_{5}{ }^{\circ}$ Thus, these precipitates could be a sodium fluozirconate or a hydrolysis product.

In preparing flowsheets, the following reaction was assumed to take place when sodium formate was added to dissolver product solution:

$$
\begin{aligned}
& 2 \mathrm{ZrF}_{4}+2 \mathrm{HF}+3 \mathrm{NaCOOH} \longrightarrow 2 \mathrm{HCOOH}+\mathrm{Na}_{3} \mathrm{Zr}_{2} \mathrm{~F}_{10}(\mathrm{COOH}) \\
& \text { - } \downarrow \mathrm{H}_{2} \mathrm{O} \\
& \mathrm{Na}_{3} \mathrm{Zr}_{2}(\mathrm{OH}) \mathrm{F}_{1 \mathrm{O}}+\mathrm{HCOOH}
\end{aligned}
$$

The insolubility of the hydrolysis product would drive the hydrolysis reaction to completion. Similar hydrolysis reactions involving sodium formate àre mentioned by Blumenthal (1).

Boildown and extraction experiments showed that uranium could not be extracted from boiled-down solutions with 10 per cent TBP in Amsco when formate ion was present. When evaporations were done in the presence of nitric acid (sodium nitrate could not be substituted for nitric acid), uranium was easily extracted. Nitric acid reacts with the formate ion to form carbon dioxide, water, and oxides of nitrogen $(2,3,4)$. The use of nitric acid in the boildown also 
permits concentration of the solution to smaller volumes without solids formation.

A. Flowsheet Utilizing Two Solid-Liquid Separations

; A flowsheet for a headend sodium formate precipitation involving a boildown with solids formation is shown in Figure 1; more detailed stream concentrations are shown in Table 1 . The precipitation is made at $60^{\circ} \mathrm{C}$ using $3.2 \mathrm{M}$ sodium formate as the precipitant. Stream volumes could possibly be reduced if slightly more concentrated sodium formate were used. The slurry should be agitated at the precipitation temperature for about 10 minutes before cooling. If filters are used, filtrations should be made with fine-porosity filters (about 5 microns). The precipitate is washed with 4 volumes of $0.1 \mathrm{M}$ sodium nitrate, each equal to one-half the volume of dissolver solution used. Filtrate and wash solutions are combined and sufficient nitric acid is added to destroy the formate ion but not to dissolve residue formed during the evaporation. The combined filtrate and wash solutions are boiled down to a volume equal to 20 per cent of the volume of dissolver solution used. Solids are removed by filtration or centrifugation and the residue washed with 3 volumes of $0.1 \mathrm{M}$ nitric acid each equal to 20 per cent of the volume of the boiled-down slurry. Filtrate and wash solution are kept separate; the wash solution is blended with the evaporator leed while the filtrate is fed to the extraction columns after aluminum nitrate and nitric acid have been added to provide salting strength and stability.

This chemical material balance. flowsheet yields an extraction feed containing only a small amount of aluminum and essentially no zirconium or fluoride. Unwelded coupons of SS 316 (extra low carbon), Hastelloy F, and Carpenter-20, located in vapor and liquid phases, gave corrosion rates of less than 2.2 mils per month under flowsheet precipitation and boildown conditions (see Appendix, sections B-6 and $\mathrm{C}-3)$.

B. Flowsheet Utilizing One Solid-Liquid Separation

A flowsheet for the precipitation of zirconium and fluoride with sodium formate followed by a boildown free from solids formation is shown 


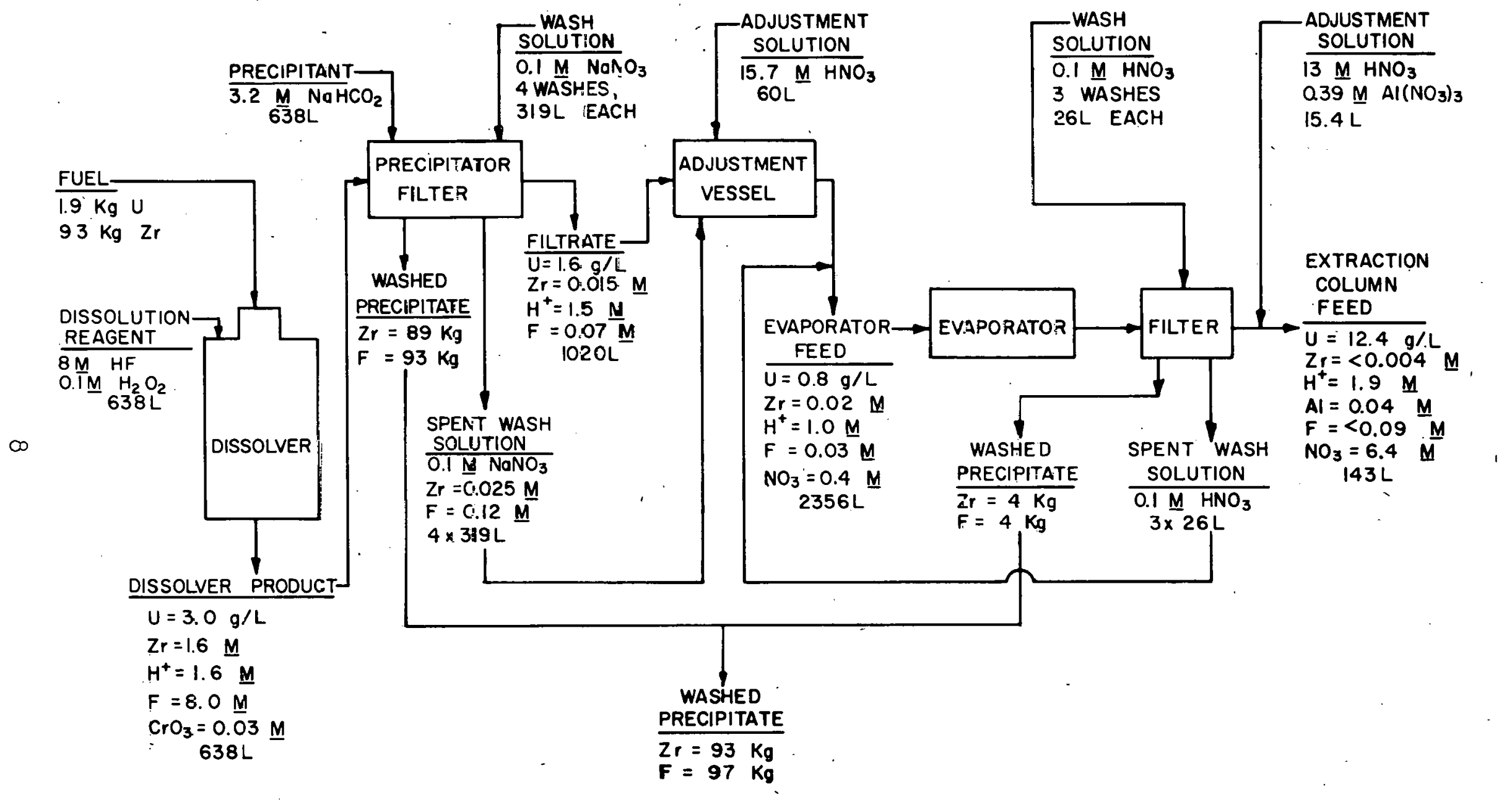

CPP-S - 2155

Fig. 1. Flowshee= for Sodium Formate Headend Precipitation Using Two Solid-Iiquid Separations 
Table 1

Material Balance for Solium Formate Headend Precipitation Using Two Solid-Liquid Separations

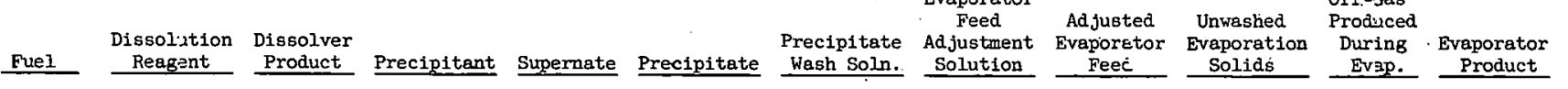
Flow,

638

$\mathrm{U} \mathrm{B}_{\mathrm{B}} / \mathrm{I} \quad 1.9 \mathrm{Kg}$

$2 r^{-} \underline{M} \quad 93 \quad K B$

Sn $\quad 1 .+\mathrm{KB}$

$\mathrm{H}^{+} \underline{\underline{\mathrm{M}}}$

$F^{-} \underline{M}$

$\mathrm{H}_{2} \mathrm{O}_{2} \mathrm{M}$

$\mathrm{CrO}_{3} \underline{\mathrm{M}}$

Na. $\mathrm{M}$

$\mathrm{HCO}^{-} \mathrm{M}$

$\mathrm{NO}_{3}^{-} \mathrm{M}$

Al $\underline{M}$

$\mathrm{SO}_{2}$

Dxides cf

$\mathrm{OH}$

$\begin{array}{cc}638 & 638 \\ 3.0 & \\ 1.6 & \\ 0.02 & \\ 1.6 & \\ 8.0 & \\ <0.005 & \\ 0.03^{*} & \\ & 3.2 \\ & 3.2 \\ & \\ & \\ & \\ & \end{array}$

$\begin{array}{cccc}1020 & 256 & 1276 \\ 1.6 & 1.9 \mathrm{~g} & \\ 0.015 & 985 \text { moles } & & \\ 0.01 & & & \\ 1.5 & & & \\ 0.07 & 4905 \text { moles } & & \\ <0.003 & & & \\ 0.02 & & & \\ 0.5 & 1470 \text { moles } & 0.1 \\ 2.0 & & & 0.1 \\ & & & \\ & & & \\ & & & \end{array}$

490 moles

Wash Soln of

(Blended Column Feed Extraction

th Adjusted Adjustment Column

Evap. Feed)

a.

* Chromic Acid was added to dissolver product. 
in Figure 2; more detailed information is shown in Table 2. The precipitation is identical to that of the flowsheet described in Table 1, with the exception that, after addition of all the precipitant, flocculating agent is added and the resulting slurry stirred at precipitation temperature. After filtration, the precipitate is washed on the filter with four portions of 0.1 nitric acid, each wash being equal in volume to one-half of the volume of dissolver solution used. Filtrate and wash solutions are combined and sufficient nitric acid added to destroy the formate ion and to prevent post-precipitation during evaporation. The combined filtrate and wash solutions are boiled down to a volume equal to 20 per cent of the volume of dissolver solution used; while this solution is still at an elevated temperature, a volume of 2.26M aluminum nitrate is added equal to 80 per cent of the volume of the boiled-down solution. Addition of aluminum nitrate stabilizes the solution and adds salting strength. This f'lowsheet eliminates a second separation step at the expense of higher corrosion during boildown, larger extraction column feed volumes, and higher concentrations of zirconium, fluoride, and aluminum in the extraction column feed. Unwelded coupons of SS 316 (ELC), Hastelloy F, and Carpenter-20, located in both the vapor and liquid phases, showed corrosion rates of less than $2.2 \mathrm{mils} / \mathrm{mo}$ under flowsheet precipitation conditions and less than $4.2 \mathrm{mils} / \mathrm{mo}$ under boildown conditions (see Appendix, sections B-6 and $\mathrm{C}-3$ ).

IV. CONCLUSIONS

Precipitates formed by the addition of sodium formate to zirconiumhydrofluoric acid dissolver solutions can remove greater than 99 per cent of the zirconium and fluoride as. solid waste, allowing concentration of the liquid waste to small volumes for storage. Solution volumes are reduced by as much as 80 per cent. Waste storage costs for the raffinates from hydrofluoric acid zirconium fuel reprocessing methods, that exist or have been proposed for use at the Idaho Chemical Processing Plant, vary from 20 to 42 per cent of the total processing costs as the production is increased from 2 to $10 \mathrm{Kg}$ of uranium per day $(5)$. Thus, a significant reduction of processing cost is 


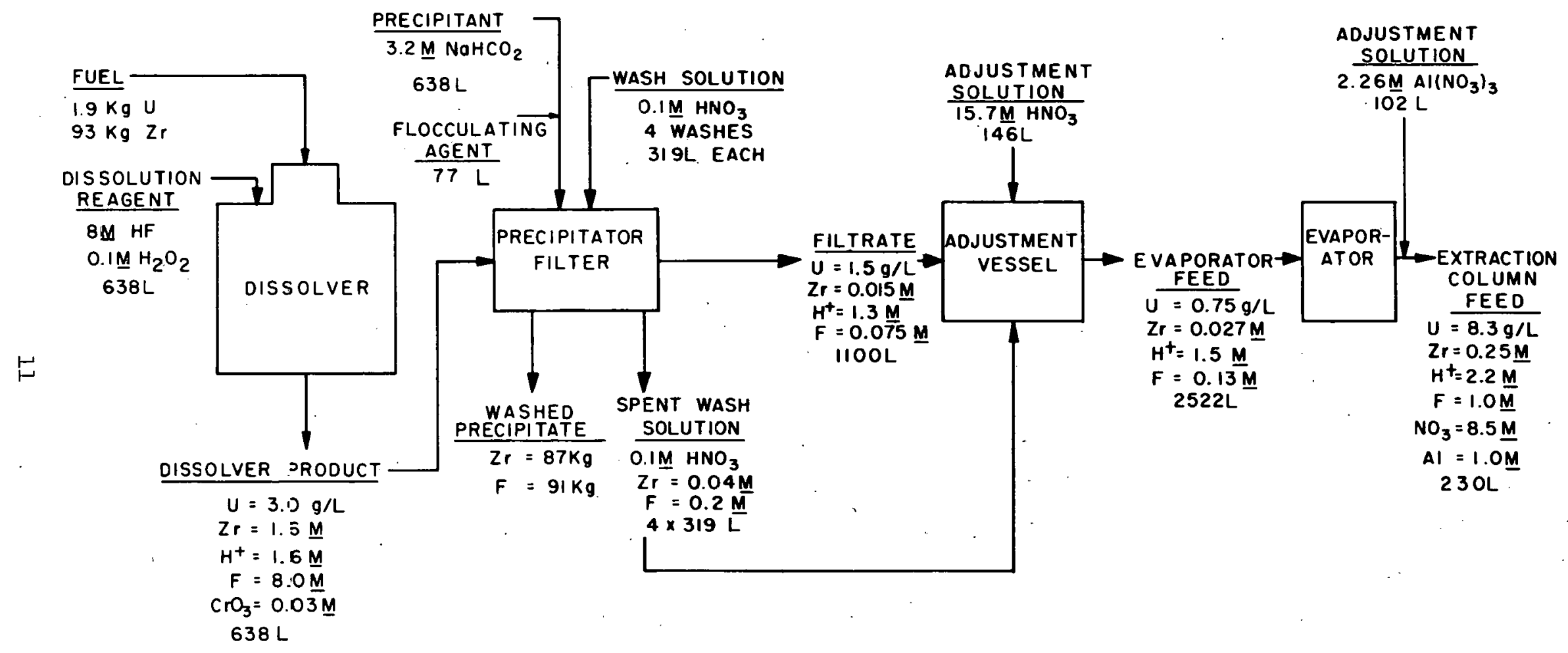

$C P P-S-2154$

Fig. 2. Flowsheet for Sodium Formate Headend Precipitation Using One Solid-Liquid Separation 
Table 2

Naterial Balance for Sodim Formate Beadend Precipitation Using one Solia-Liquid Separation

Dissolution
Reagent $\stackrel{\begin{array}{l}\text { Jissolver } \\ \text { Product }\end{array}}{\text { Precipstant }} \begin{aligned} & \text { Floceulating } \\ & 0.1 \% \text { Reagest* }\end{aligned}$

Flow,

$1 /$ batch

U $\mathrm{g} / 11.9 \mathrm{Kg}$

2r $\quad \underline{M} 93 \quad \mathrm{~KB}$

$\mathrm{Sn} \quad \underline{\mathrm{M}} 1.4 \mathrm{Kg}$

$\mathbf{B}^{+} \underline{M}$

$\mathrm{F}^{-} \underline{\underline{M}}$

$\mathrm{H}_{2} \mathrm{O}_{2} \stackrel{M}{M}$

$\mathrm{CrO}_{3}$

Na $\underline{M}$

$\mathrm{HCO}_{2}-\mathrm{M}$

$\mathrm{NO}_{3}, \frac{\mathrm{M}}{\mathrm{M}}$

$\mathrm{CO}_{2}$

Oxides of Nitroge

OH
$638-638$

3.0

1.6

$8.0 \quad 1.6$

$\begin{array}{ll}8.0 & 8.0 \\ 0.1 & <0.005\end{array}$

$0.03 *$

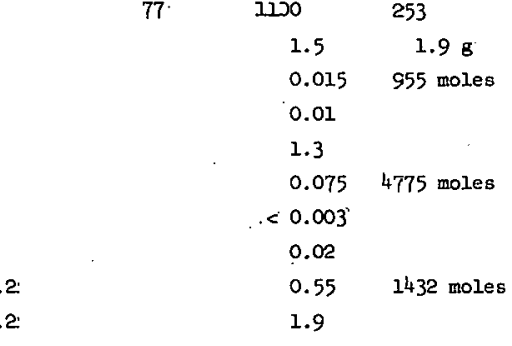

Floceulating
O.1\% Reagest*

Stpernate Frecipitate

Precipitate

Evaporeto

Feed

Solution

Aajjusted

vaporator Evaporator

Off-Gas Extraction

Produced
During
Evap. $\begin{gathered}\text { Adjustment } \\ \text { Solution }\end{gathered}$

Extraction Wash Soln. Solution

2276

\begin{tabular}{|c|c|c|}
\hline \multirow[t]{2}{*}{146} & 2522 & 128 \\
\hline & 0.75 & 14.8 \\
\hline \multirow[b]{2}{*}{ ' } & 0.027 & 0.45 \\
\hline & 0.004 & 0.08 \\
\hline \multirow[t]{6}{*}{15.7} & 1.5 & 4.0 \\
\hline & 0.13 & 1.8 \\
\hline & $<0.001$ & $<0.02$ \\
\hline & 0.009 & 0.15 \\
\hline & 0.24 & 5.6 \\
\hline & 0.81 & \\
\hline 15.7 & 0.96 & 9.9 \\
\hline
\end{tabular}

102

230

4.8
0.45
0.08

0.1

0.02

0.1

9.9

2042 moles

1154 moles
2.2

$<0.01$

0.08

3.1

6.8

2.26

8.5

* This can je $0.1 \%$ by we1ght Jeneral Mills' Galactasol CAM, Dow's Sepaxar. NP-10, Stein Hell's Jaguar, or Cyanamia's Aercfloc 350 Reagent.

* Chroric azid was added to sissolver product. 
possible by using the sodium formate precipitation process in. combination with one of these reprocessing methods.

Since the sodium formate precipitation reaction is complete within 5 minutes after precipitant addition, it may also be conveniently adapted to continuous zirconium fuel dissolutions.

All streams involved in the flowsheet of Figure 1 are non-corrosive to materials of construction commonly used in the atomic energy industry. Thus, the materials that must be used to fabricate a precipitator, solid-liquid separation devices, evaporator, and adjustment vessels are readily available. An 80 per cent volume reduction can be realized prior to uranium extraction. This flowsheet produces an extraction column feed that contains negligible fluoride concentrations and appears to be quite stable. Such a stream should be non-corrosive to stainless steel extraction columns. The raffinate from the extraction column is low in aluminum and contains eesentially no zirconium or fluoride; thus, the solids content of the material to be stored is low.

The flowsheet of Figure 2 eliminates a second solid-liquid separation step. However, the construction materials used to fabricate the evaporator used in the boildown may be a problem, since unwelded coupons gave corrosion rates varying from 2.8 to $4.2 \mathrm{mils} / \mathrm{mo}$ when subjected to boildown conditions. This chemical material balance provides for a 64 per cent volume reduction prior to extraction. The flowsheet uses an extraction column feed with a higher aluminum-to-fluoride mole ratio than the process being currently used at the ICPP or in the flowsheets proposed by Parrett ${ }^{(6)}$ for future hydrofluoric acid dissolutions; thus, the stream should be non-corrosive to stainless steel extraction columns. The extraction column feed appeared to be stable at room temperature. The density of the extraction column raffinate is higher than in the other sodium formate flowsheet.

Fluoride and zirconium recovery should not be aftected by variation in dissolver solution fluoride concentration, provided the fluoride-tozirconium mole ratio is 5 or less; good recoveries at higher mole 
rátios would require sodium formate-to-zirconium mole ratios greater than 2 to 1: Sodium formate solutions of $6 \mathrm{M}$ might be used as a precipitant, which would decrease many of the process stream volumes considerably.

Uranium losses to the precipitates from the sodium formate process are comparable to the usual over-all process losses, but are somewhat. high for a single step of an enriched uranium process. Effective removal from solids requires that the uranium be in its highest state of oxidation; chromic acid is a convenient oxidizing agent. At the end of four washes with a wide variety of $0.1 M$ wash solutions, each wash having one-half the volume of the dissolver product solution, the uranium loss to the sodium precipitate decreases to about 0.1 per cent and approaches the limit of effectiveness. Washing solids (formed during boildown) 3 times with a volume of dilute nitric acid. equal to one-fifth the volume of bolled-down slurry results in a uranium loss of 0.03 per cent and approaches the limit of effectiveness. 


\section{LITERATURE CITED}

1. Blumenthal, Warren B., The Chemical Behavior of Zirconium, pp. 314317, D. Van Nostrand Company, Inc., New York, 1958.

2. Adams, Warren H., Eric B. Fowler, and C. W. Christenson, A Method for Treating Radioactive Nitric Acid Wastes Using Paraformaldehyde, Industrial and Engineering Chemistry, Vol. 52, No. 1, pp. 55-56, January 1960.

3. Evans, T. F., The Pilot Plant Denitration of Purex Wastes with Formaldehyde, HW-58587, February 23, 1959 (Unclassified).

4. Morris, J. B., The Reaction of Nitric Acid with Formaldehyde, AERE-CE/R-1490, 1954 (Official Use Only).

5. Burn, P., An Evaluation of Various Zirconium Fuel Reprocessing Methods for Possible Installation at the Idaho Chemical Processing Plant, IDO-14564, in press.

6. Parrett, 0. W., Modifications for the STR Fuel Recovery Process, IDO-14522, December 15, 1960, (Unclassified). 


\section{APPENDIX}

A. Experimental Methods and Materials

1. Zirconium Alloy Fuel Solutions

The zirconium dissolver product stock solution was prepared by dissolving zirconium alloy fuel pieces in sufficient hydrofluoric acid to produce a 5-to-l mole ratio of fluoride to zirconium. Hydrogen peroxide was added to oxidize the uranium and to prevent precipitation of uranium tetrafluoride. The fuel pieces consisted of zirconium-uranium alloy meat sections clad with Zircaloy-2. These samples averaged about 3.0 weight per cent uranium. The stock solution was 1.6M zirconium, 8.0M fluoride, $1.6 \mathrm{M}$ acid, and contained 3.7 grams of' uranium per liter. 'l'o determine how the I'luoride-to-zirconium mole ratio of the dissolver solutions affected the sodium formate precipitation, solutions having a mole ratio greater than 5 were prepared. These increased mole ratios were obtained by addition of concentrated hydrofluoric acid.

\section{Equipment and Procedure}

Precipitations and boildowns were made in polypropylene equipment using either a mechanically driven Teflon stirrer or a magnetic stirrer with a l'eflon stirring bar. Precipitations made at $60^{\circ} \mathrm{C}$ or at lower temperatures were carried out in tall beakers without attempting to prevent loss due to evaporation; those made at a temperature above $60^{\circ} \mathrm{C}$ were carried out under total reflux. Except for experiments in which zirconium recovery was studied as a function of stirring time and sodium formate concentration, slurries resulting from precipitant addition (with or without the presence of flocculating agents) were allowed to stir at the precipitation temperature for one-half hour. The slurry was then cooled to room temperature and vacuum filtered through a fine-(4-5.5 microns) porosity sintered glass f'ilter.

\section{Analytical Methods}

Most of the solids were dissolved for analytical purposes by heating in dilute nitric acid. However, a few of the solids required prolonged heating with various combinations of boric, hydrofluoric, nitric, sulfuric, or hydrochloric acids to dissolve them. 
The methods that were used to analyze solutions or solids for zirconium, fluoride, nitrate, uranium, and acid are reported in "The Manual of Analytical Methods of the Control Laboratory at the Idaho Chemical Processing Plant", IDO-14316, edited by M. J. Shepherd, Jr., and J. E. Rein.

Total carbon and hydrogen were analyzed by direct combustion. Flame photometry was used for all sodium analyses.

B. Precipitation of Zirconium and Fluoride with Sodium Formate

1. Effect of Sodium Formate Concentration

The effect of sodium formate concentration on the recovery of zirconium after stirring for one hour at room temperature and at elevated temperature under total reflux is shown in Figure 3. A solution of 3.2M sodium formate was used as the precipitant. In addition, the effect of sodium formate-to-zirconium mole ratio in the range 1.5 to 2.0 was determined at $60^{\circ} \mathrm{C}$ using a one-half hour stirring time. Zirconium recovery over this range gradually increased from 89.6 per cent at the lower ratio to 97.4 per cent at the upper ratio. These results indicate that a sodium formate-to-zirconium mole ratio of two is adequate for good zirconium removal from solution.

The addition of precipitant as a solution more concentrated

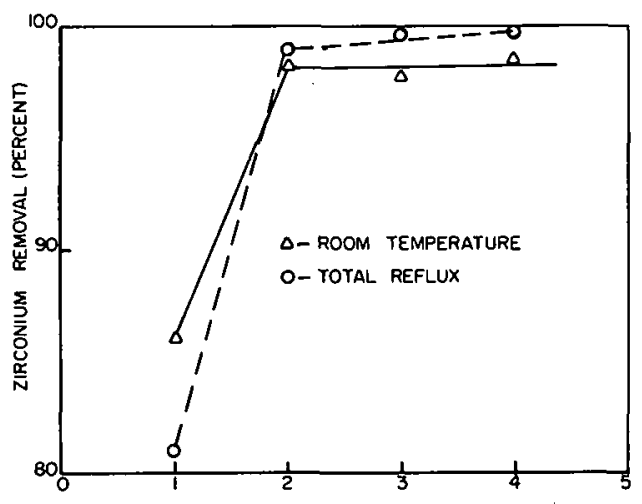

MOE RATO OF SODIUM FORMATE TO ZIRCONIUM

Fig. 3. Effect of Sodium Formate Concentration on Zirconium Recovery

Precipitate was from a. snlution containing $1.6 \mathrm{M} \mathrm{Zr}, 8.0 \mathrm{M} \mathrm{F}, 1.6 \mathrm{M}$ $\mathrm{H}^{+}$, and $3.7 \mathrm{~g} / \overline{\mathrm{I}} \mathrm{U}$. $3.2 \overline{\mathrm{M}}$ sodium formate used as the precipitant. Reaction time was 1 hour. than 3.2M would have the desirable effect of decreasing stream volumes. Therefore, precipitations were made using $8.0 \mathrm{M}$ sodium formate as the precipitant; however, greater volumes of wash solution were necessary to remove uranium from precipitates formed with $8.0 \mathrm{M}$ than with 3.2M sodium formate under identical conditions. Increased wash solution volumes negaled lie volume decreases realized by the use of $8.0 \mathrm{M}$ sodium formate solutions. In addition, slurries formed by the use of $8.0 \mathrm{M}$ 
precipitant were too thick for handling in process equipment. The use of a precipitant concentration between 3.2 and $8 \mathrm{M}$ - may be feasible; however, no laboratory data were obtained in this concentration range.

\section{Effect: of Reaction Time}

At appropriate time intervals during the reaction between 3.2M sodium formate and uranium-Zircaloy dissolver solution, aliquots of slurry were removed, filtered, and the filtrate analyzed for zirconium. The sodium formate-to-zirconium mole ratio in these experiments was 2 to 1 ; and two temperatures, room temperature and boiling temperature with total reflux, were used. The precipitation reaction was rapid, as shown in Figure 4; it was complete within 5 minutes over the temperature range studied and was nearly complete in $?$ minuties.

\section{Wash Solution Studies}

Water and $0.1 \mathrm{M}$ solutions of 7 different reagents were tested for their ability to remove uranium from precipitates formed by the sodium formate precipitation. Precipitates were formed at $60^{\circ} \mathrm{C}$ from untreated stock dissolver solutions, from stock dissolver solutions boiled about 10 minutes with 30 per cent hydrogen peroxide added immediately before precipitation, and from solutions made 0.03M in chromic acid prior to precipitation. Others were prepared at room

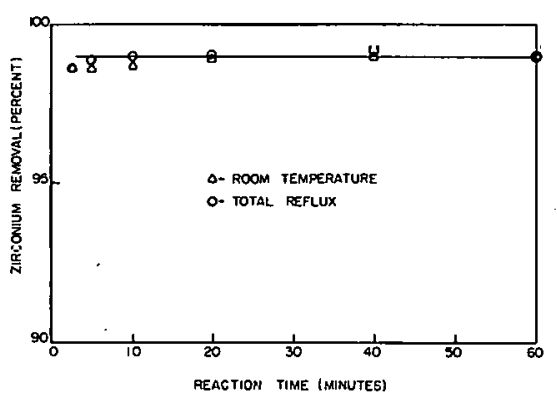

Fig. 4. Effect of Reaction Time on Zirconium Recovery

Precipitate was from a solution containing $1.6 \mathrm{M} \mathrm{Zr}, 8.0 \mathrm{M} \mathrm{F}$, $1.6 \mathrm{M} \mathrm{H}^{+}$, and $3.7 \mathrm{~g} / 1 \mathrm{U} .3 .2 \mathrm{M}$ sodium formate used as the precipitant. Sodium formate-tozirconium mole ratio was 2 to 1 . temperatiure or at refluxing temperatures from untreated solutions. Approximately $8.5 \mathrm{~g}$ of residue was washed with four 12.5-ml aliquots of wash solution. Wash solutions tested in addition to water were nitric acid, hydrofluoric acid, formic acid, sodium formate, sodium nitrate, sodium t'luoride, ammonium nitrate, ammonium fluoride, and aluminum nitrate. Table 3 summarizes the uranium removal and precipitate dissolution data pertinent to 
each system. About 20 per cent of the uranium originally. in the dissolver solution was held tightly by residues formed at room temperature from untreated solutions and could not be washed off with any of the wash solutions. The. slow addition of sodium formate solution to dissolver solutions at elevated temperatures with stirring decreased the amount of uranium lost to the solid. When this technique was preceded by oxidizing all of the uranium in solution to the hexavalent state, uranium losses were decreased to less than 0.3 per cent.

Table 3 points out that the water and acid washes dissolved more of the precipitate than did the washes containing sodium, but were not much more effective for uranium removal. Water, the alumirnum nitrate wash, and the acid washes contained residue immediately after contact with the precipitate, while the washes containing sodium were stable for at least a day; only a trace of residue was found in the sodium washes after a week.

Studies were also performed to determine the smallest volume of wash solution necessary for effective uranium removal from the precipitates. These experiments were done both with and without the addition of flocculating agent $(6 \mathrm{ml}$ of 0.1 per cent, General Mills' Galactasol CAM). Precipitates were formed at $60^{\circ} \mathrm{C}$ using $50 \mathrm{ml}$ of dissolver solution (0.03M in chromic acid) and $50 \mathrm{ml}$ of 3.2M sodium formate solution. Wash solutions studied were $0.1 \mathrm{M}$ solutions of nitric acid, formic acid, sodium formäte, and sodium nitrate. The results of successive washings using nitric acid without a flocculating agent as the wash solution are plotted as an equilibrium curve in Figure 5. In the calculation of the operating. line, the total weight of precipitate was corrected for the weight of the individual samples removed for analysis. The awount of uranium remaining in the precipitate after one wash was 2.4 per cent. At the end of four washes, the amount remaining had decreased to about 0.2 per cent, and washing had approached the limit of effectiveness. Curves obtained with the other wash solutions were very similar. Both of the sodium washes resulted in about a 2 per cent 


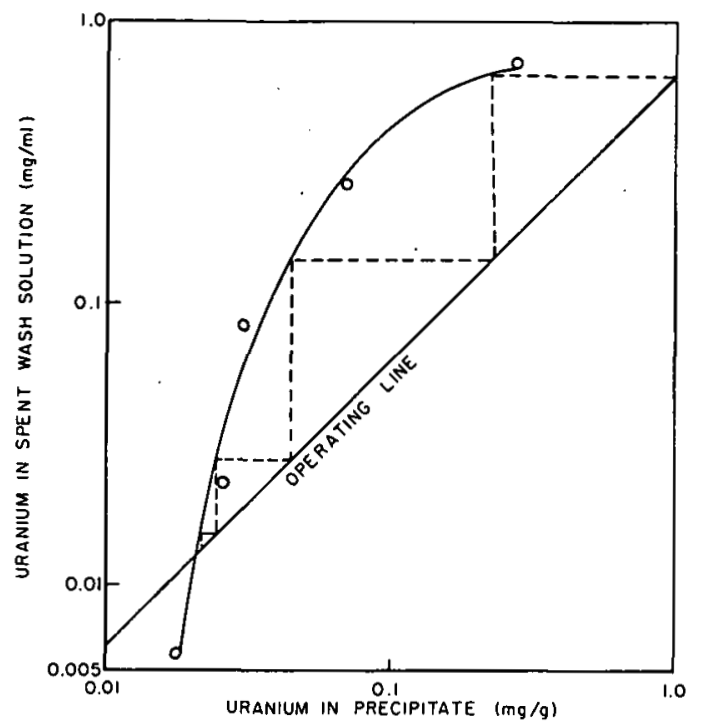

Fig. 5. Uranium Equilibrium Curve for Precipitate Washing

Precipitate: $16 \mathrm{~g}$ prepared from $50 \mathrm{ml}$ of STR solution containing $0.03 \mathrm{M}_{2} \mathrm{CrO}_{3}$ and $3.7 \mathrm{~g} / \mathrm{I}$ uranium.

Washes: $25 \mathrm{ml}$ each using $0.1 \mathrm{M}$ $\mathrm{HNO}_{3}$ at $20^{\circ} \mathrm{C}$.

Precipitate Treatment: Filtered and dried at $105^{\circ} \mathrm{C}$ for analysis. zirconium loss to the wash solutions; the acid washes resulted in a zirconium loss two to three times higher.

4. Effect of Temperature and Flocculating Agents

Laboratory experiments were performed to investigate the effect of precipitation temperature and quantity of flocculating agent on the physical characteristics of the precipitate and the stability of the filtrate. The temperature range investigated was from room temperature to reflux temperature. Flocculating agents studied were potato starch, General Mills' Galactasol CAM, Dow's Separan NP-10, Stein Hall's Jaguar, and Cyanamid's Aerofloc 550 Reagent.

The precipitates formed below $60^{\circ} \mathrm{C}$ had to be formed by adding the sodium formate precipitant rapidly to prevent the formation of thick immobile slurries. The addition of flocculating agents to this system did not prevent post-precipitation in the filtrates and wash solution.

The precipitates formed at or above $60^{\circ} \mathrm{C}$ were granular and fast settling, and the physical appearance of the precipitate was independent of the rate of precipitant addition. The addition of $40 \mathrm{mg} /$ liter of slurry of all the flocculating agents (with the exception of potato starch) produced a filtrate free from residue and decreased the solubility of the precipitate in the wash solutions.

The precipitates formed at reflux temperature were granular and fast settling, the filtrates were free of residue, and the precipitates were relatively insoluble in the wash solutions. Flocculating agents 
had no apparent beneficial effects.

5. Fluoride and Zirconium Concentrations in Dissolver Solution Since the fluoride-to-zirconium mole ratio of dissolver solutions may vary, experiments were performed to determine whether an increase in this ratio would reduce zirconium and fluoride removal. Removal was decreased from about 97 to 91 per cent as the fluoride-tozirconium mole ratio was increased from 5 to 6 (see Table 4 ). Increasing the fluoride-to-zirconium mole ratio also resulted in a precipitate with higher fluoride-to-zirconium and sodium-to-zirconium mole ratios, even though the sodium formate concentration was constant.

\section{Corrosion}

Tests were performed to determine the corrosion resistance at $60^{\circ} \mathrm{C}$ of unwelded coupons of SS 316 (extra low carbon), Carpenter-20, Monel, and Hastelloy $\mathrm{F}$, in the following systems:

(1) slurries produced by the reaction of zirconium dissolver solutions (0.03M in chromic acid) with sodium formate (both with and without flocculating agents), and (2) zirconium dissolver solutions which were $0.03 \mathrm{M}$ in chromic acid. These media are expected to bracket all conditions occurring during precipitation. The expected corrosion rates for precipitation-vessel materials should be between the corrosion rate in the slurry to which all precipitant had been added and the corrosion rate in the solution prior to precipitant addition. Sodium formate was added in this corrosion experiment as an 8-molar solution at the rate of 2 moles per mole of zirconium. The flocculating agent used was Stein Hall's Jaguar at a concentration of $6 \mathrm{ml}$ of 0.1 per cent Jaguar for every $50 \mathrm{ml}$ of dissolver solution. Tests lasted 48 hours, and coupons of each material were suspended within, at the surface, and above the slurry. Monel was tested in a nitrogen atmosphere. Table 5 shows that all of these materials except Monel could be considered for the construction of a precipitation vessel. C. Boildown and Extraction Studies

1. Boildown with Solid Formation, Followed by Extraction The volume of solution resulting from sodium formate 
Table 4

Effect of Fluoride-to-Zirconium Mole Ratio

on Sodium Formate Precipitation

Conditions: Two moles of sodium formate added per mole of zirconium present; precipitation temperature $=60^{\circ} \mathrm{C}$; dissolver solution composition originally was $1.6 \mathrm{M} \mathrm{Zr}, 0.03 \mathrm{M} \mathrm{Cr}^{+6}, 3.7 \mathrm{~g} / \mathrm{l} \mathrm{U}, 8.0 \mathrm{M} \mathrm{F}$ and $1.6 \mathrm{M} \mathrm{H}{ }^{+}$; $\mathrm{F}$ varied by $\mathrm{HF}$ addition; precipitate washed 4 times with a volume of $0: 1 \mathrm{M} \mathrm{NaNO}_{3}$ equal to $1 / 2$ the dissolver solution volume.

F-to-Zr Mole Ratio of Dissolver Solution F-to-Zr Mole Ratio Na-to-Zr Mole Ratio

\% $\mathrm{Zr}$ loss to Filtrate \% $\mathrm{F}$

5.0
5.2
5.7

1.5
2.1
2.4

$\begin{array}{rr}2.7 & <3.0 \\ 5.4 & 5.8 \\ 5.9 & 9.0\end{array}$

5.5

6.0
5.7
1.5
2.1
2.4

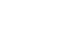


Table 5

Corrosion During the Precipitation of Zircorium and

- Fluoride with Sodium Formate

Conditions: Temperature $=60^{\circ} \mathrm{C}$; 2 moles of sodium formete added per mole of $\mathrm{Zr}$; dissclver solution composition - 1.6 $\mathrm{M} \mathrm{\textrm {Ar }}, 1.6 \mathrm{M} \mathrm{H}^{+}, 8 \mathrm{M} \mathrm{F}$, $0.03 \mathrm{M} \mathrm{CrO}_{3}, 3.7 \mathrm{~g} / 1 \mathrm{U}$; flocculating agent $-6 \mathrm{ml}$ of $0.1 \%$ stein Hall's Jaguar per $50 \mathrm{ml}$ of dissolver solution; length of test 48 hours.

Construction Material (unwelded)

SS 316 (ELC)
Monel
Hastelloy F

*Pitted
Corrosion in Slurry . Containing Flocculating

. Agent

(milis/mo)

liquid interface vapor

$\begin{array}{lrr}0.03 & <0.03 & <0.03 \\ 2.5 & 0.99 & 0.18 \\ 0.03 & 0.04 & 0.02 \\ 0.03<0.03 & <0.03\end{array}$

$0.03<0.03<0.03$

$<0.03<0.03<0.03$
Corrosion in Slurry Without Flocculaiting

Corrosion in Dissolver Soln. which is $0.03 \mathrm{M}$ chromic acid (mils/mo)

liquid interface vapor liquid interface vapor

$\begin{array}{rrrrrr}<0.03 & <0.03 & <0.03 & 0.79 & 2.1 & 1.6 \\ 9.1 & 4.3 & 0.42 & 25^{*} & 5.8 * & <0.03 \\ 0.07 & 0.08 & 0.07 & 0.52 & 0.63 & 0.32 \\ <0.03 & <0.03 & <0.03 & 0.53 & 0.33 & 0.24\end{array}$

Agrnt

\section{(mils/mo)}

0.53 
precipitation from dissolver solution followed by evaporation of the filtrates and washes can be reduced to 20 per cent of the original dissolver solution volume without the formation of a thick slurry:

\section{a) Boildown Studies}

A few studies were performed to determine how boildown was affected by precipitation temperatures, flocculating agents, oxidants, and boildown techniques. Twenty-five milliliters of 3.2M sodium formate solution was added at $60^{\circ} \mathrm{C}$ or boiling temperature to $25 \mathrm{ml}$ of dissolver solution which was either 0.03 or $0.06 \mathrm{M}$ in chromic acid or had been treated with hydrogen peroxide. The precipitations carried out at boiling in the presence of a flocculating agent contained $40 \mathrm{mg}$ of Jaguar per liter of slurry; those carried out at $60^{\circ} \mathrm{C}$ with a flocculating agent contained $60 \mathrm{mg}$ per liter. The precipitates were filtered and washed 4 times with $12.5 \mathrm{ml}$ of $0.1 \mathrm{M}$ sodium nitrate, and the wash solution and filtrate were combined. The resulting solution was boiled down to either. 4 or $10 \mathrm{ml}$, and the resulting slurry filtered and washed again. The $5 \mathrm{ml}$ of solution used to wash the solid from the $4 \mathrm{ml}$ of slurry was combined with the filtrate for analysis; that used to wash the solid from the $10 \mathrm{ml}$ of slurry was kept separate from its filtrate and the two analyzed separately. In experiments involving hydrogen peroxide, the oxidant was added continually during boildown and also used in the $0.1 M$ sodium nitrate wash solutions.

A summary of the uranium removed from precipitates, the fluoride and zirconium removed from filtrates, the solids produced during boildown, as well as other information obtained during these boildown experiments, is shown on Table 6 . Chromic acid was much more efficient than hydrogen peroxide in keeping uranium in the hexavalent state; no difference could be discerned between the efficiency of the two chromic acid concentrations used. None of the other variables studied had any appreciable effect on the boildown.

b) Wash Solution Studies Studies were performed to determine the smallest volume 
Table 6

Bcildown Characteristics of Filtrates and 0.1M Sodium Nitrete Wash

Solutions Froduced During Sodium Formate Precipitat1cn

Conditions: Precipitate was formed by adding $25 \mathrm{ml}$ of $3.2 \mathrm{M}$ sodium formste solusion to $25 \mathrm{ml}$ of dissolver soluticn; 8.5 gn of sodium formate precipitate was washed four times with $12.5 \mathrm{ml}$ of $0.1 \mathrm{M} \equiv 0$ dium nitrate.

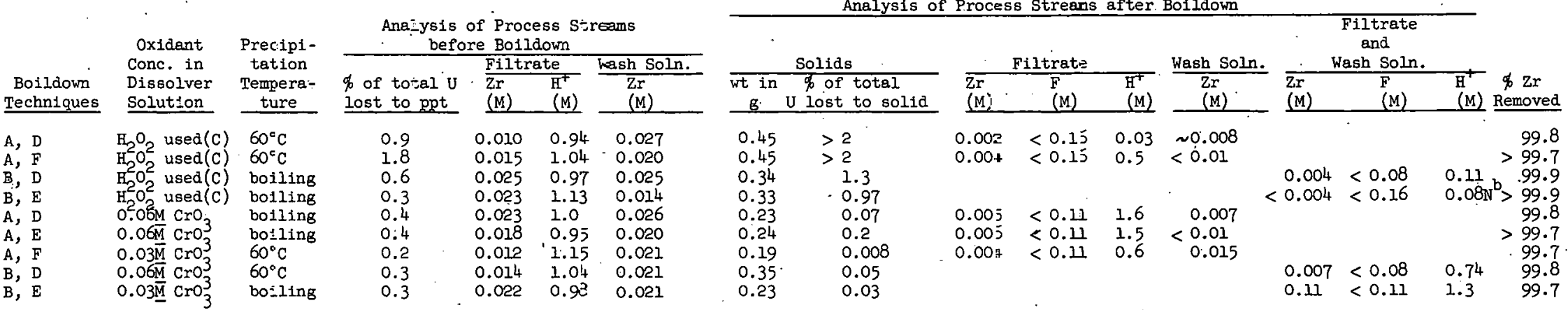

A) $52 \mathrm{ml}$ of $0.1 \mathrm{M} \mathrm{NaNO}_{3}$ and $25 \mathrm{ml}$ of filtrate was boiled down to $10 \mathrm{ml}$, the resulting residue was filterel and washed 4 times with $1.5 \mathrm{ml}$ of $0.1 \mathrm{M} \mathrm{NaNO}$; the latter wash solution and filtrate were kept separate.

B) $52 \mathrm{ml}$ of $0.2 \mathrm{MaNO}_{3}$ and $25 \mathrm{ml}$ of filtrate vas boiled down to $4 \mathrm{ml}$, the resulting residue was ziltered and washed 4 times with $1.5 \mathrm{ml}$ of $0.1 \mathrm{M}$ NaNO${ }_{3}$; the latter wash solution and filtrate sere combined.

c) $25 \mathrm{ml}$ of dissolver-solution was boiled 10 ainutes with $1-1 / 2 \mathrm{ml}$ of 30 per cent $\mathrm{H}_{2} \mathrm{O}_{2}$ prior to scdium formate precipitation; 2 ml of 30 per cent $\mathrm{H}_{2} \mathrm{O}_{2}$ was added a little at a time during the boildown; $0 . \mathrm{IM} \mathrm{NaNO}_{3}$ wash solations were made $2.8 \mathrm{M}^{2}$ in $\mathrm{H}_{2} \mathrm{O}_{2}$ before using-

D) No flocculating agent present.

E) Precipitation carried ous in the presence of $40 \mathrm{mg}$ of Jagia: per liter of slurry.

F) Precipitation carried out in the presence of $60 \mathrm{mg}$ of Jaguas per liter of slurry. 
of $0.1 \mathrm{M}$ nitric acid or sodium nitrate necessary for effective uranium removal from the solids which separated out during boildown. The solids for the washing experiments were formed by adding, at $60^{\circ} \mathrm{C}$, $50 \mathrm{ml}$ of $3.2 \mathrm{M}$ sodium formate to an equal volume of dissolver solution, $0.03 \mathrm{M}$ in chromic acid. The resulting slurry was stirred for one-half hour, the precipitate filtered and washed with four $25-\mathrm{ml}$ aliquots of $0.1 \mathrm{M}$ sodium nitrate. Four and six-tenths milliliters of 15. TM nitric acid was added to the combined filtrate and wash solution, and the resulting solution was boiled down to $10 \mathrm{ml}$ and filtered. The $0.7 \mathrm{~g}$ of residue separating out during evaporation was washed various times with fresh 2-ml aliquots of wash solution. The results of uranium analysis of the liquid and solid phases were plotted as equilibrium curves similar to that shown in Figure 5. At the end of three washes, the uranium lost to the solids decreased to about 0.03 and 0.1 per cent when 0.1 M nitric acid and sodium nitrate were used, respectively, and the washing approached the limit of effectiveness as shown by equilibrium curves. A zirconium loss of 0.1 and 0.4 per cent to the wash solution (due to the solubility of the solid) occurred when the solids were washed 3 times with $2 \mathrm{ml}$ of $0.1 \mathrm{M}$ sodium nitrate or nitric acid, respectively. One-tenth molar ni-tric acid is the more effective wash for removing uranium from the solids. Since the used wash solution can be kept separate from the filtrate and added to successive combined filtrates and wash solutions prior to boildown, the somewhat greater solubility of residue in nitric acid is not of great importance.

c) Solution Adjustment Prior to Extraction Several studies were performed to determine the amount of nitric acid in the boildown which would lead to low fluoride and zirconium supernate concentrations and also to uranium distribution coefficients greater than 10 when the filtrate was contacted with 10 per cent TBP in Amsco. In these experiments, the preparation of the solid containing zirconium and fluoride and the washing of the resulting precipitate was identical to that described for the wash solution studies of part VI-R-3. The wash solutions and filtrates were combined, various amounts of $15.7 \mathrm{M}$ nitric acid were added, the 
resulting solution boiled down to a volume equal to 20 per cent of the dissolver solution volume, and the slurry filtered. Some of these filtrates were extracted with no further treatment. In some cases, nitric acid and aluminum nitrate or aluminum nitrate alone were added prior to TBP extraction.

As shown in Table 7, the addition of 72 millimoles of nitric acid to $100 \mathrm{ml}$ of wash solution plus $80 \mathrm{ml}$ of filtrate prior to boildown results in a solution that, when evaporated to the appropriate volume and filtered, yields a filtrate containing almost no zirconium and fluoride ions and from which uranium can be effectively extracted with TBP. However, addition of varying amounts of aluminum nitrate or aluminum nitrate and nitric acid is required to stabilize the solution. The effect of these additions is shown in Table 7; 4.5 millimoles of aluminum nitrate or 0.45 millimole of aluminum nitrate and 16 millimoles of nitric acid stabilizes the solution and provides good extraction characteristics. The combination of aluminum nitrate and nitric acid is preferable, since it adds less non-volatile material to the system.

2. Boildown Without Solid Formation, Followed by Extraction During the boildown experiments described in Table 7, it was observed that the allowable concentration factor before the onset of solids formation increased with increasing nitric acid addition. Accordingly, some experiments were done to study boildown conditions leading to stable evaporator products from which no solids formed. Precipitation conditions were as summarized in Table $7 ; 11.4 \mathrm{ml}$ of 15.7M nitric acid was added to the supernate before boildown. Varying amounts of aluminum nitrate were also added, either before or after conceritration.

The smallest stable concentrate volumes occurred when the addition of aluminum nitrate was made after evaporation and when a flocculating agent (Jaguar) was used during the precipitation. In experiments using 0.1 M nitric acid as wash solution, slightly smaller stabilized volumes could be obtained than when 0 . I M sodium nitrate was used under the same conditions. Optimum results were obtained for an evaporator 
Table 7

Boildown and Extraction Characteristics of Filtrates Produced During Sodium Formate Precipitation Followed by a $0.1 \mathrm{M}$ Nitric Acid or Sodium Nitrate Wash

Conditions: Precipitate was formed by adding $50 \mathrm{ml}$ of $3.2 \mathrm{M}$ sodium formate solution to $50 \mathrm{ml}$ of dissolver solution $\left(0.03 \mathrm{M}\right.$ in chromic aci.1) with stirring for $1 / 2$ bour at $60^{\circ} \mathrm{C}$; 16 gur of sodium formate precipitate was washed 4 times with $25 \mathrm{ml}$ of $0.1 \mathrm{M} \mathrm{NaNO}_{3}$; $\mathrm{HNO}_{3}$ was added to the combined $80 \mathrm{ml}$ of filtrate and $100 \mathrm{ml}$ of wash solution and the resulting solution boiled down to $10 \mathrm{ml}$.

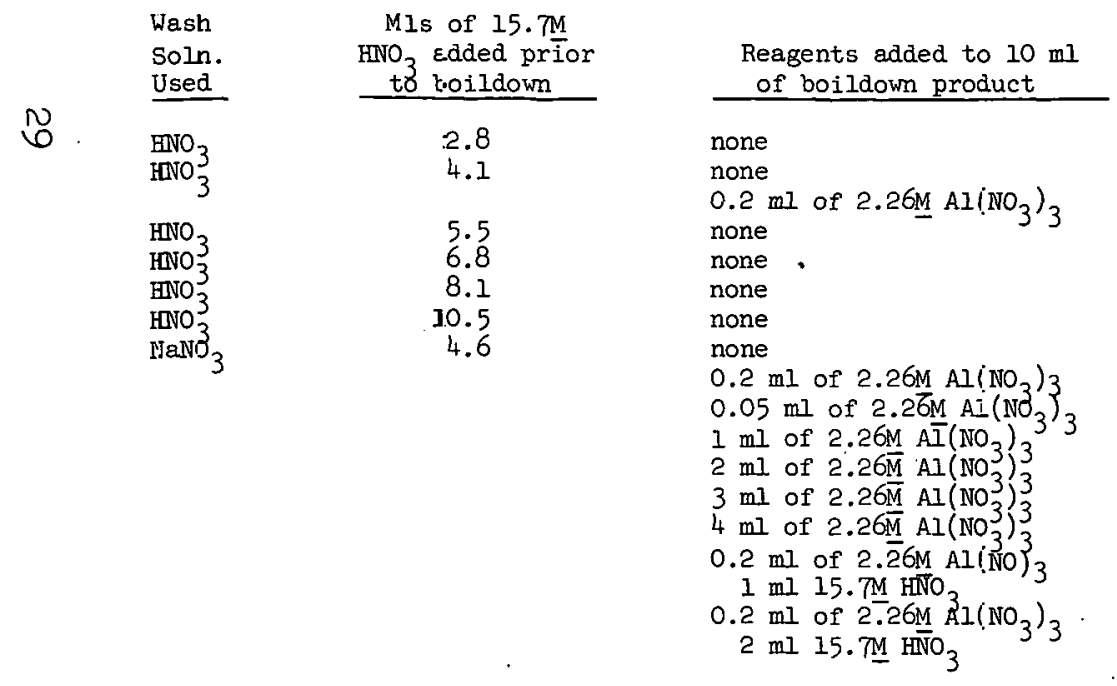

\begin{tabular}{|c|c|c|c|}
\hline \multicolumn{4}{|c|}{$\begin{array}{l}\text { Analysis of Boildown } \\
\text { Product After } \\
\text { Reagent Addition }\end{array}$} \\
\hline $\begin{array}{l}\mathrm{Zr} \\
(\mathrm{M})\end{array}$ & $\begin{array}{l}\mathrm{H}^{+} \\
(\mathrm{M})\end{array}$ & $\begin{array}{l}F^{-} \\
(M)\end{array}$ & $\begin{array}{l}\mathrm{Na}^{+} \\
\text {(M) }\end{array}$ \\
\hline 0.023 & 0.76 & -- & -- \\
\hline 0.021 & 0.46 & -- & -- \\
\hline 0.007 & 0.62 & $<0.10$ & 2.7 \\
\hline 0.20 & 0.63 & -- & -- \\
\hline 0.17 & 1.10 & -- & -- \\
\hline 0.16 & 1.81 & -- & -- \\
\hline 0.23 & 4.3 & -- & -- \\
\hline 0.021 & 0.46 & -- & -- \\
\hline 0.005 & 0.69 & $<0.10$ & 3.2 \\
\hline$-\cdots$ & ---- & -- & -- \\
\hline 0.005 & 0.81 & $<0.10$ & -- \\
\hline -..... & 0.56 & -- & -- \\
\hline$\cdots$ & 0.38 & -- & -- \\
\hline -.... & 0.29 & -- & -- \\
\hline ---- & 0.77 & -- & -- \\
\hline ---- & 1.36 & -- & -- \\
\hline
\end{tabular}

\begin{tabular}{l}
$\begin{array}{c}48 \text {-hour } \\
\text { statility } \\
\text { of bcildown } \\
\text { prcduct }\end{array}$ \\
\hline unstable \\
unstable \\
unstable \\
unstable \\
unstable \\
unstable \\
unstable \\
unstable \\
stable \\
unstable \\
unstable \\
stable \\
stable \\
stable \\
stable \\
stable
\end{tabular}

Extraction of

with $10 \%$ TBP

in Amsco

\begin{tabular}{ccc}
\hline $\begin{array}{c}\text { U in } \\
\text { Aqueous } \\
(\mathrm{g} / \mathrm{l})\end{array}$ & $\begin{array}{c}\text { in in } \\
\text { Organic } \\
(\mathrm{g} / \mathrm{l})\end{array}$ & $\mathrm{E} \frac{\mathrm{O}}{\mathrm{a}}$ \\
\hline 2.97 & 12.21 & 4.1 \\
1.01 & 12.55 & 12.4 \\
4.14 & 10.84 & 2.6 \\
0.66 & 11.97 & 18 \\
0.49 & 12.28 & 25 \\
0.42 & 9.50 & 23 \\
1.68 & 13.97 & 8.3 \\
1.01 & 12.55 & 12.4 \\
4.24 & 10.40 & 2.5 \\
$-1 .-$ & $-1 .--$ & ---- \\
2.03 & 11.69 & 5.8 \\
0.92 & 9.27 & 10 \\
0.22 & 10.16 & 46 \\
0.20 & 8.75 & 44 \\
& & \\
0.33 & 11.71 & 35 \\
0.34 & 10.84 & 32
\end{tabular}


feed composed of the following: $80 \mathrm{ml}$ of filtrate containing a flocculating agent; $100 \mathrm{ml}$ of $0.1 \mathrm{M}$ nitric acid washes; and $11.4 \mathrm{ml}$ of $15.7 \mathrm{M}$ nitric acid. After concentration of such a solution to 10 $\mathrm{ml}$, the addition of $8 \mathrm{ml}$ of $2.26 \mathrm{M}$ aluminum nitrate before cooling produces an extraction feed of the following composition: $0.25 \mathrm{M} \mathrm{Zr}, 1.0 \mathrm{M} \mathrm{F}, 2.2 \mathrm{M} \mathrm{H}^{+}, 3 . \underline{\mathrm{M} \mathrm{Na}} \mathrm{N}^{+}, 1.0 \mathrm{M} \mathrm{Al}+3$, and $8 \mathrm{~g} / \mathrm{I}$. Such a solution is stable for at least two weeks, and a uranium extraction coefficient of 27 was achieved when it was contacted with an equal volume of 10 per cent TBP in Amsco. This method of boildown avoids any solids formation during the evaporation step, but results in a greater extraction volume and higher concentrations of aluminum, fluoride, and zirconium in the extraction t'eed.

\section{Corrosion}

rihe corrosion resistance of unwelded couporss of SS 316 (extra low carbon), Carpenter-20, and Hastelloy $F$ was tested during concentration. Evaporations were approximately 48 hours in duration, and coupons were immersed within the media and suspended above the media. In one series of boildowns, $13.8 \mathrm{mi}$ of $15.7 \mathrm{M}$ nitric acid was added to $240 \mathrm{ml}$ of filtrate plus $300 \mathrm{ml}$ of $0.1 \mathrm{M}$ sodium nitrate (prepared as described in Table 7, using three times the volumes), and the resulting solution boiled down to $48 \mathrm{~m}$. In the other series, $34.2 \mathrm{ml}$ of $15.7 \mathrm{M}$ nitric acid was added to $258 \mathrm{ml}$ of filtrate containing $18 \mathrm{ml}$ of 0.1 per cent Jaguar plus $300 \mathrm{ml}$ of 0 . IM nitric acid wash solution, and the resulting solution boiled down to $48 \mathrm{ml}$. Coupons tested in the former evaporations showed no discernible corrosion; those tested in the latter system (immersed within the media) showed corrosion rates varying from 2.8 to 4.2 mils per month (see Table 8). 
Table 8

Corrosion During the Boildown of Filtrates and Wash Solutions Formed from the Precipitation of Zirconium and Fluoride with Sodium Formate

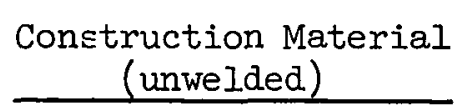

Stainless steel 316(ELC)

Stainless Steel 316(ELC)

Hastelloy $\mathrm{F}$

Hastelloy $F$

Carpenter -20

Carpenter -20

\begin{abstract}
Boildown
Description
\end{abstract}

\section{A}

B

A

B

A

B

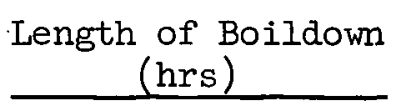

53

48.5

48

48.5

44

48.5

\begin{tabular}{|c|c|}
\hline \multicolumn{2}{|c|}{$\begin{array}{l}\text { Corrosion } \\
\text { mils/mo }\end{array}$} \\
\hline Liquid & Vapor \\
\hline$<0.04$ & $<0.04$ \\
\hline 4.2 & 0.53 \\
\hline$<0.04$ & $<0.04$ \\
\hline 3.5 & 0.43 \\
\hline$<0.04$ & $<0.04$ \\
\hline 2.8 & 0.76 \\
\hline
\end{tabular}

A. $240 \mathrm{ml}$ of filtrate (prepared by adding $150 \mathrm{ml}$ of $3.2 \mathrm{M}$ sodium formate at $60^{\circ} \mathrm{C}$ to $150 \mathrm{ml}$ of dissolver solution - $0.03 \mathrm{M}$ in $\mathrm{CrO}_{3}$ ) plus $300 \mathrm{ml}$ of $0.1 \mathrm{M} \mathrm{NaNO}_{3}$ used to wash the precipitate plus $13.8 \mathrm{ml}$ of $15.7 \mathrm{M} \mathrm{HNO}_{3}$ boiled down to $48 \mathrm{ml}$.

B. $258 \mathrm{ml}$ of filtrate (prepared by adding $150 \mathrm{ml}$ of $3.2 \mathrm{M}$ sodium formate at $60^{\circ} \mathrm{C}$ to $150 \mathrm{ml}$ of dissolver solution ( $0.03 \mathrm{M}$ in $\left.\mathrm{CrO}_{3}\right)$ in the presence of $18 \mathrm{ml}$ of 0.1 per cent Jaguar) plus $300 \mathrm{ml}$ of $0.1 \mathrm{M} \mathrm{HNO}_{3}$ used to wash the precipitate plus $34.2 \mathrm{ml}$ of $15.7 \mathrm{M}^{\mathrm{HNO}} \mathrm{H}_{3}$ boiled down to $48 \mathrm{ml}$. 


\section{PHILLIPS}

PETROLEUM

COMPANY

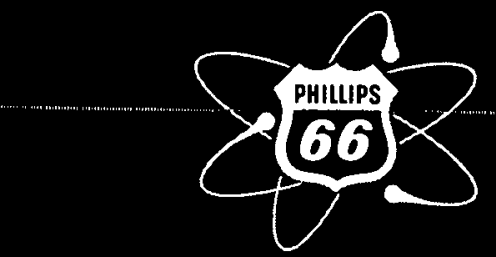

ATOMIC ENERGY DIVISION 